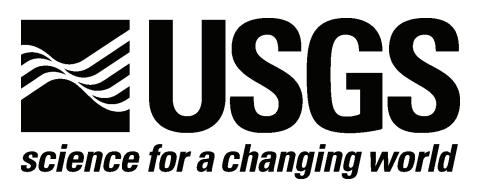

Prepared in cooperation with the U. S. Department of Energy Office of Environmental Management, National Nuclear Security Administration, Nevada Site Office, under Interagency Agreement DE-Al52-01NV13944

\title{
Preliminary gravity inversion model of basins east of Yucca Flat, Nevada Test Site, Nevada
}

By Geoffrey A. Phelps, Carter W. Roberts, and Barry C. Moring

Open-File Report 2005-1313

U.S. Department of the Interior

U.S. Geological Survey 


\section{U.S. Department of the Interior \\ Gale A. Norton, Secretary}

\section{U.S. Geological Survey \\ P. Patrick Leahy, Acting Director}

U.S. Geological Survey, Reston, Virginia 2005

For product and ordering information:

World Wide Web: http://www.usgs.gov/pubprod

Telephone: 1-888-ASK-USGS

For more information on the USGS - the Federal source for science about the Earth, its natural and living resources, natural hazards, and the environment:

World Wide Web: http://www.usgs.gov

Telephone: 1-888-ASK-USGS

Any use of trade, product, or firm names is for descriptive purposes only and does not imply endorsement by the U.S. Government.

Although this report is in the public domain, permission must be secured from the individual copyright owners to reproduce any copyrighted material contained within this report. 


\title{
Preliminary gravity inversion model of basins east of Yucca Flat, Nevada Test Site, Nevada
}

\author{
By Geoffrey A. Phelps, Carter W. Roberts, and Barry C. Moring
}

\begin{abstract}
The Yucca Flat eastern extension study area, a 14 kilometer by 45 kilometer region contiguous to Yucca Flat on the west and Frenchman Flat on the south, is being studied to expand the boundary of the Yucca Flat hydrogeologic model. The isostatic residual gravity anomaly was inverted to create a model of the depth of the geologic basins within the study area. Such basins typically are floored by dense pre-Tertiary basement rocks and filled with less-dense Tertiary volcanic and sedimentary rocks and Quaternary alluvium, a necessary condition for the use of gravity modeling to predict the depth to the pre-Tertiary basement rocks within the basins. Three models were created: a preferred model to represent the best estimate of depth to pre-Tertiary basement rocks in the study area, and two end-member models to demonstrate the possible range of solutions. The preferred model predicts shallow basins, generally less than $1,000 \mathrm{~m}$ depth, throughout the study area, with only Emigrant Valley reaching a depth of $1,100 \mathrm{~m}$. Plutonium valley and West Fork Scarp Canyon have maximum depths of $800 \mathrm{~m}$ and 1,000m, respectively. The endmember models indicate that the uncertainty in the preferred model is less than $200 \mathrm{~m}$ for most of the study area.
\end{abstract}

\section{Introduction}

The Yucca Flat extensional basin is located in the northeast corner of the Nevada Test Site (Fig. 1). Neighboring basins include Emigrant Valley to the east and Frenchman Flat to the southeast. The Halfpint Range, composed primarily of moderately west-dipping Paleozoic and Precambrian sedimentary rocks in the north and gently west-dipping Tertiary volcanic rocks in the south, separates Yucca Flat from Emigrant Valley. Several small valleys, including Plutonium Valley, lie within the low hills of the Halfpint Range between Yucca Flat and Emigrant Valley. Paleozoic and Precambrian sedimentary rocks, and to a lesser extent Mesozoic intrusive rocks in the northern Halfpint Range, form the basement of the valleys onto which Tertiary and Quaternary rocks and alluvial sediments have been deposited.

The U.S. Department of Energy's Environmental Restoration Program is constructing a hydrologic model to predict groundwater flow in the area as part of an effort to quantify the subsurface hydrology of the Nevada Test Site. Constructing such a model requires approximating the shapes of the geologic units in the subsurface, a task for which gravity inversion modeling can be helpful. Of particular interest is the depth and extent of the lower carbonate aquifer, a thick section of Paleozoic-age limestones and dolomites that act as the dominant regional aquifer for this part of Nevada (Winograd and Thordarson, 1975). The depth to the top of this section, and the location and orientation of any faults that are present, are key elements in a model that help predict 
whether potentially contaminated water could migrate from local basins into the larger aquifer system, where it could possibly constitute a human health hazard. The shape and approximate depth of basins, defined as the interface between pre-Tertiary basement rocks and the younger basin-filling units, can be effectively modeled using the gravity inversion technique developed by R.C. Jachens (Jachens and Moring, 1990; Saltus and Jachens, 1995). This technique was used to model the depth and shape of Yucca Flat basin (Phelps and others, 1999), a key structural geologic element in the Yucca Flat hydrogeologic model (Gonzales and others, 1998; Gonzales and Drellack, 1999). The Yucca Flat hydrogeologic model will be used as the primary geologic input in a study of flow and transport in Yucca Flat basin. Phase I regional hydrogeologic modeling revealed that flow from underground testing sites in eastern Yucca Flat approached the eastern edge of the area defined by theYucca Flat model. Discussions with flow and transport modelers indicated a need to extend the Yucca Flat model beyond its initial boundary on the east side to model flow in the eastern direction. The modelers proposed to expand the model to the east, including the Halfpint Range and the western portions of Emigrant Valley, in the newest version of the Yucca Flat hydrogeologic model. The boundary of the eastern extension is shown in figure 1. This report applies gravity inversion techniques to develop a model of basin depths for the eastern extension of Yucca Flat model. 


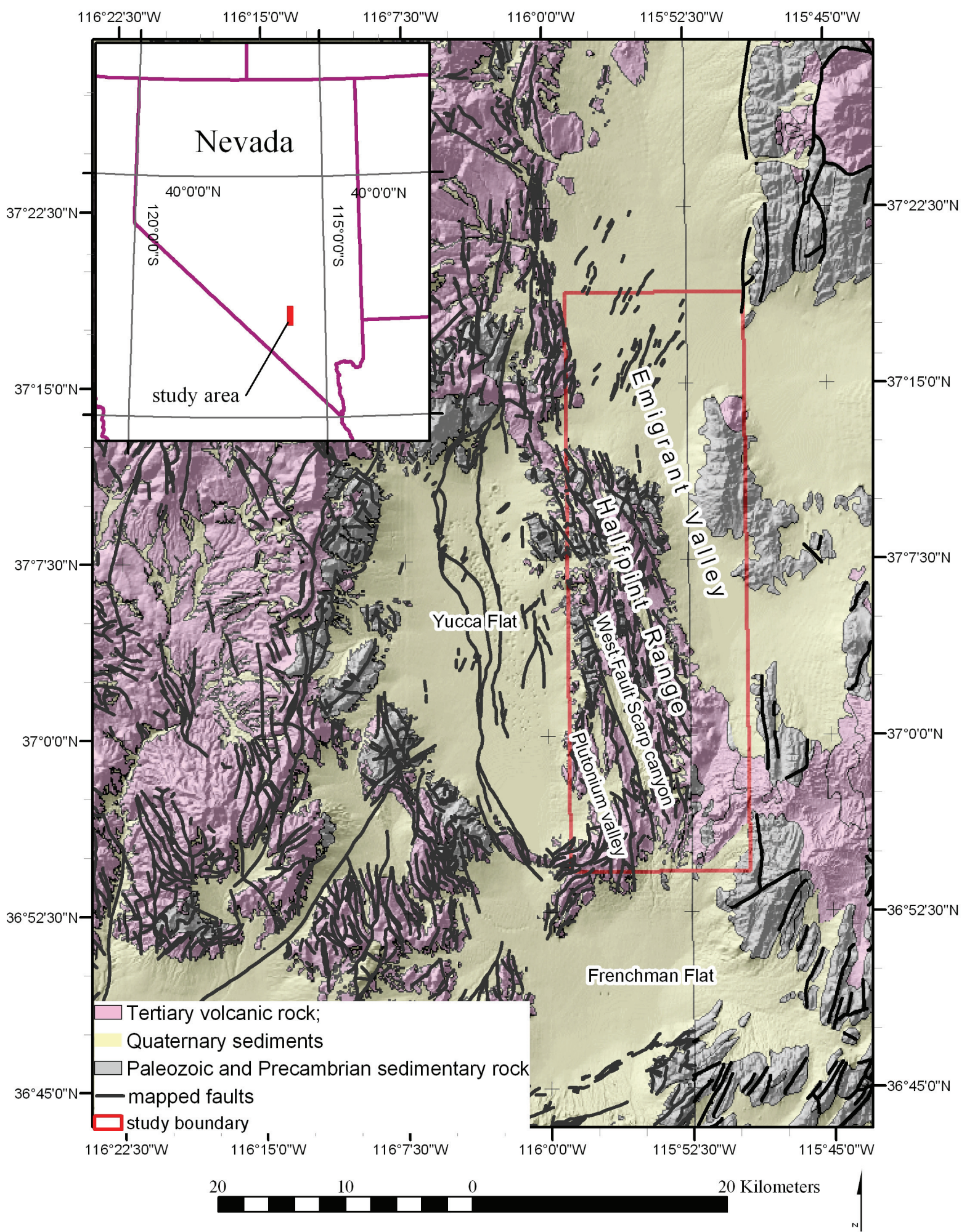

Figure 1. Map of study area showing simplified geology and major place names. Shaded relief map compiled from merged $30 \mathrm{~m}$ DEMs. Geology simplified from Wahl and others, 1997, Slate and others, 1999, and Raines and others, 2003. 


\section{Gravity data}

The isostatic residual gravity anomaly reflects density variations in the upper $10 \mathrm{~km}$ of the earth's crust. It is derived from the complete Bouguer anomaly by removing the gravitational component due to isostatic compensation of topography (Jachens and Griscom, 1985). The isostatic residual gravity anomaly is inverted in this study to estimate the shape and depth of basins in the eastern extension study area.

Gravity data were reduced using the Geodetic Reference System of 1967 (International Union of Geodesy and Geophysics, 1971) and referenced to the International Gravity Standardization Net 1971 gravity datum (Morelli, 1974). Gravity data were reduced to complete Bouguer gravity anomalies (Plouff, 1977) with a reduction density of $2670 \mathrm{~kg} / \mathrm{m}^{3}$ by applying earth-tide, instrument drift, free-air, Bouguer, latitude, curvature, and terrain corrections. An isostatic correction, following the method and parameters used by Jachens and Griscom (1985), was applied to produce the final isostatic gravity anomaly. Assuming a sea level crustal thickness of $25 \mathrm{~km}$ based on seismic profiles, a crustal density above sea level of $2670 \mathrm{~kg} / \mathrm{m}^{3}$, and a mantlecrust density contrast of $400 \mathrm{~kg} / \mathrm{m}^{3}$, the correction removed the long-wavelength gravitational effect caused by isostatic compensation of topography.

Gravity data are measured at individual locations on the ground throughout the study area, resulting in a scattered data set. After the data are reduced to find the isostatic residual gravity anomaly, the scattered data are interpolated using a bi-cubic spline (Briggs, 1974) to generate an estimate of the isostatic residual gravity anomaly at any given point in the study area. 


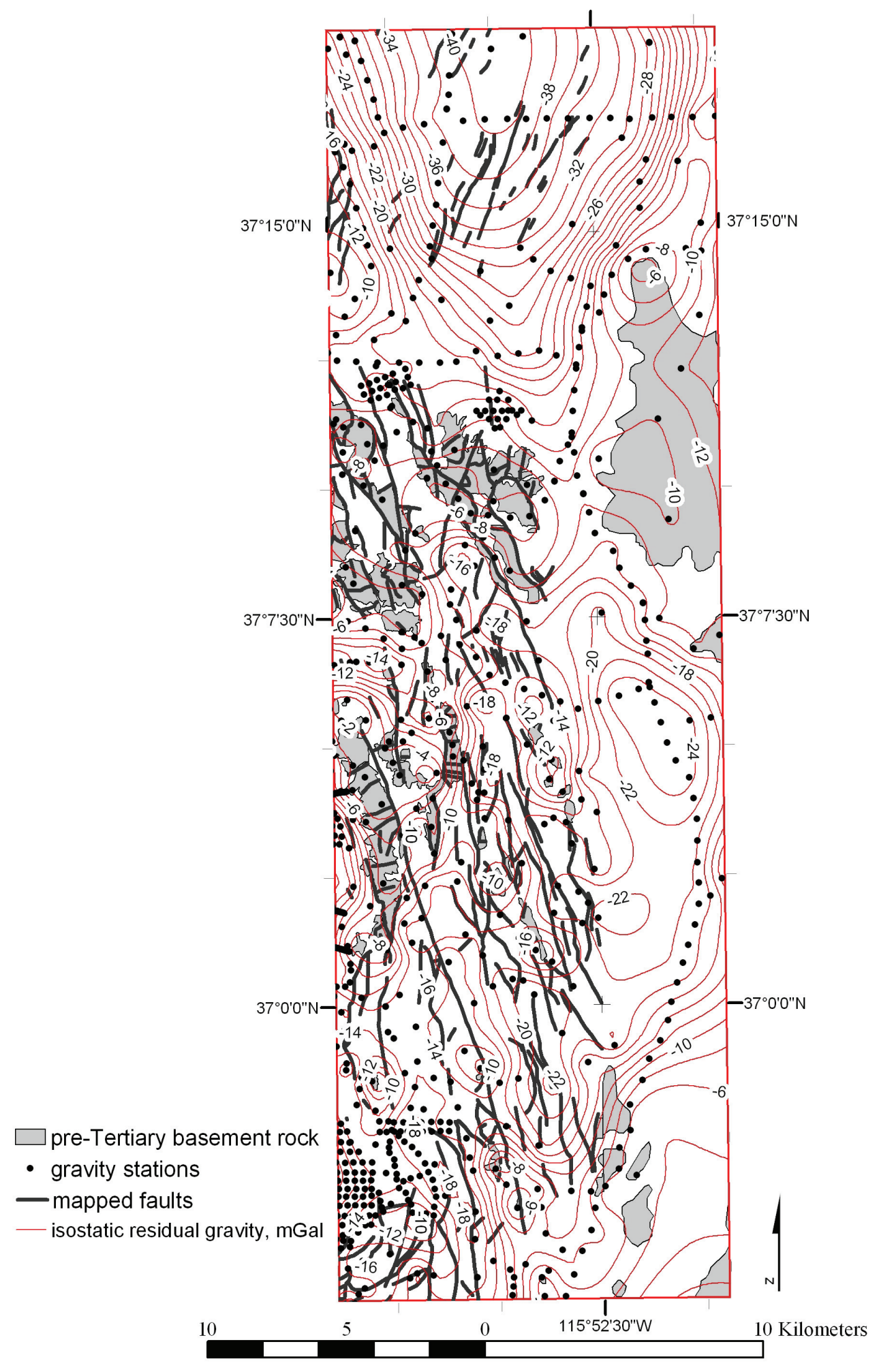

Figure 2. Map of the study area showing the gravity measurement stations and the resulting isostatic residual gravity field. Geology simplified from Wahl and others, 1997, Slate and others, 1999, and Raines and others, 2003. 
Gravity data for the eastern extension study area were taken from an existing dataset of gravity stations from the Nevada Test Site (Ponce, 1997). A total of 1,214 stations in the eastern extension study area were used in the modeling process. 73 gravity stations are located on outcrops of Paleozoic rocks in the Halfpint Range (figure 2). The station spacing in the eastern extension is variable, and this has an effect on the resolution of the model used. A histogram of the distance to the nearest gravity measurement for the study area can help create an understanding of the spatial resolution of the gravity data. Such a histogram can be approximated by plotting a histogram of the number of square grid cells that are within a given distance from the nearest gravity measurement (as measured from the center of each cell). Figure 3 shows such an approximation using 200 meter grid cells. Half of the study area is within $600 \mathrm{~m}$ of the nearest gravity measurement, and $90 \%$ of the study area is within 1,500m of the nearest gravity measurement. In general, half of the study area can detect geologic features creating a gravitational anomaly of roughly $600 \mathrm{~m}$ or greater, and most of the study area can detect geologic features creating a gravitational anomaly of roughly $1,500 \mathrm{~m}$ or greater.

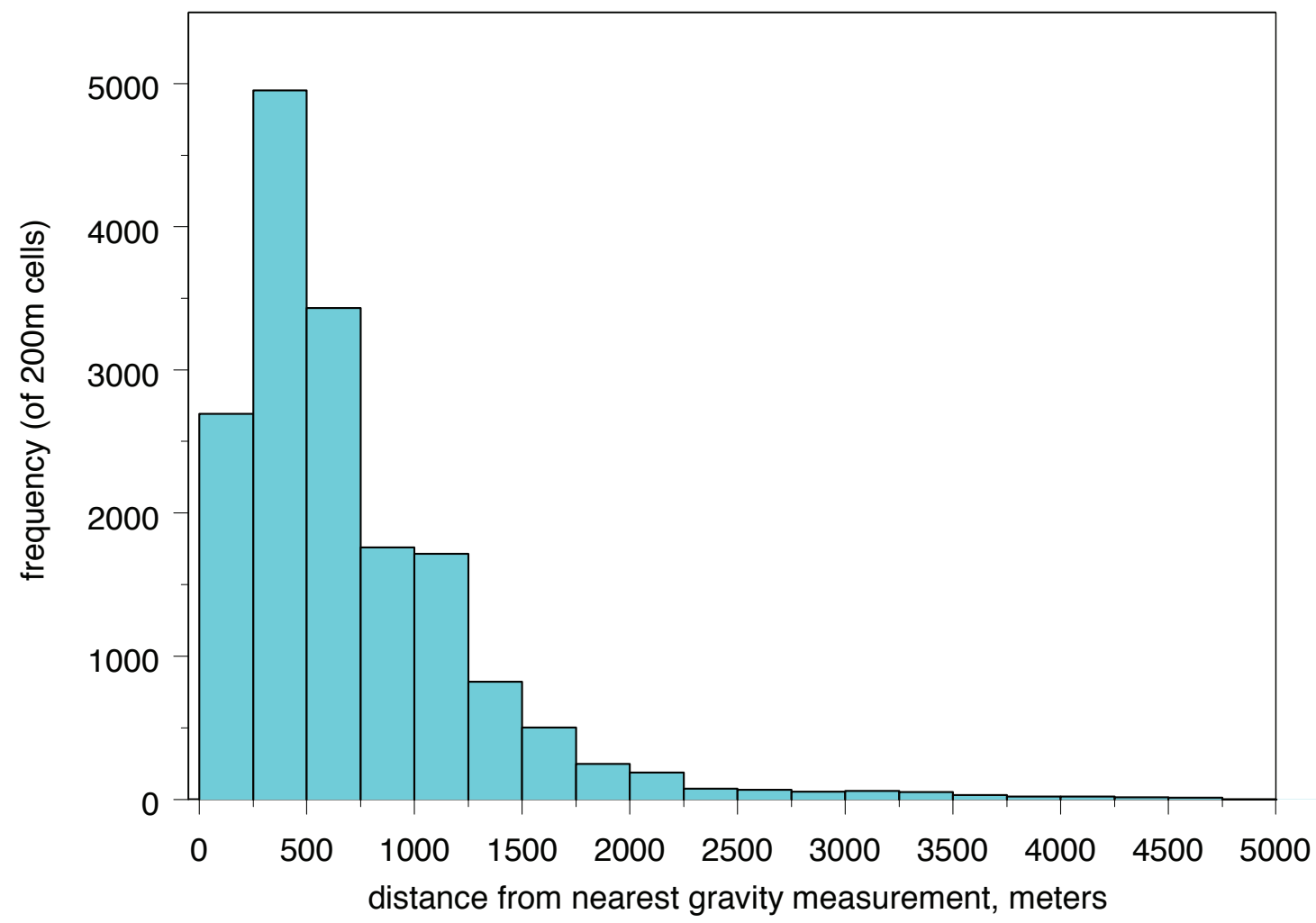

Figure 3. Histogram of the area (approximated by the number of 200 meter grid cells) a given distance from the nearest gravity measurement. Approximately $50 \%$ of the study area is within 600 meters, and approximately $90 \%$ of the study area is within 1500 meters, of the nearest gravity measurement.

The isostatic residual gravity anomaly shows that most of the basins in the eastern extension study area are small, shallow basins (fig. 2). A low area of the anomaly in Emigrant Valley is a 
prominent exception, with a value of $-41.7 \mathrm{mGals}$ at its lowest point. The anomaly across the eastern extension indicates that, in general, sediments filling basins are relatively thin.

\section{Depth to basement modeling}

Modeling the depth to basement depends on the density contrast between basement rock and basin fill. A method developed by Jachens and Moring (1990) separates the observed gravity into two components: that produced by dense basement rocks and that produced by less dense overlying basin-filling deposits. The density of basin-filling deposits is defined according to a specified density profile, which varies vertically through the sediment column. This component is directly inverted in order to provide an initial estimate of the thickness of deposits. The gravitational effect of the deposits is then factored into the component of the gravitational anomaly produced by the basement rocks, modifying that component. The process is then repeated until the solution converges.

Gravity inversion modeling requires an estimate of the densities of the rock units filling the basin and the underlying basement rocks. The dense basement rocks are inferred to be preCenozoic rocks, based on both local and regional outcrop and regional drill-hole data (see, for example, Stewart and Carlson, 1978; Slate and others, 1999; Cole and others, 1997). In the model, the basement rocks of the model are assumed to have the standard reduction density for gravity data of $2670 \mathrm{~kg} / \mathrm{m}^{3}$, a value that is in close agreement with the density of basement rocks measured, using borehole gravity meters, in Yucca Flat (Phelps and others, 1999).

The densities of the basin-filling rocks that occur in northern Yucca Flat on the Nevada Test Site have been extensively studied and documented (Burkhard, 1989). Table 1 lists the average densities for rocks making up the majority of the basin-filling rock units. These data can be used to estimate the average density of the rocks that fill the basins in the eastern extension. The density data used to develop Table 1 are primarily measured using gamma-gamma logs; however some borehole gravity and hand sample measurements were also incorporated (G. Pawloski, personal communication). Borehole gravity data from both northern and southern Yucca Flat, when analyzed collectively (Phelps and others, 1999), yield slightly higher average density values (Table 1 , numbers in parentheses). This could be due to a difference in the way instruments measure density (instruments that measure borehole gravity average density over a much larger range than gamma-gamma measurement devices), spatial heterogeneity within the units, or a combination of both.

Few drill-holes penetrate the sedimentary rocks in the study area (figure 1), so the composition of the basin-filling rocks is not known for the majority of the area. Geologic crosssections and mapping (Hinrichs and McKay, 1965; Byers and Barnes, 1967; Barnes and others, 1965) suggest that the basin-filling rocks are primarily Tertiary volcanic rocks, particularly the Ammonia Tanks and Rainier Mesa Tuffs of the Timber Mountain Group, and the Paintbrush Group, with some older volcanic rocks present in the northern part of the study area. The valleys also contain varying amounts of late Cenozoic alluvium.

If the primary composition of the basin-filling rocks were volcanic rocks with densities as low as those published by Burkhard, the density contrast with the basement rocks would be approximately $1000 \mathrm{~kg} / \mathrm{m}^{3}$. However, the basins are likely to contain a certain percentage of denser alluvium, in which case the density contrast with the basement rocks would be slightly less, approximately $900 \mathrm{~kg} / \mathrm{m}^{3}$. Alternatively, the density of the basin-filling sediments might be higher and follow a more complex density model, where density increases with depth, such as neighboring 
Yucca Flat (Phelps and others, 1999). In this case the difference in densities between the basement and basin-filling rocks would continue to decrease with depth. These three alternatives were chosen as reasonable models to represent the range of possible densities for the basin-filling sediments. The density contrast of $900 \mathrm{~kg} / \mathrm{m}^{3}$ was chosen as the preferred value for the difference in density between the basement and basin-filling rocks, with the other two representing possible end-member values (Table 2). The actual density of basin-filling sediments depends upon the subsurface spatial distribution and thickness of each contributing geologic unit, which is not known. The potential for variability in the thickness and distribution of subsurface geologic units, and their internal heterogeneity, is shown by the average standard deviation in table 1 (which assumes equal contribution from each geologic unit). 


\begin{tabular}{|c|c|c|c|}
\hline Unit & $\begin{array}{l}\text { Average density } \\
\mathrm{kg} / \mathrm{m}^{3}\end{array}$ & $\begin{array}{l}\text { Standard } \\
\text { Deviation }\end{array}$ & Rock Unit \\
\hline QTal & $\begin{array}{l}1900 \\
(1980)\end{array}$ & $\begin{array}{l} \pm 120 \\
( \pm 160)\end{array}$ & Tertiary \& Quaternary alluvium \\
\hline QTma & 1960 & \pm 100 & mixed Tertiary \& Quaternary alluvium \\
\hline QTta & 1790 & \pm 110 & basal tuffaceous alluvium \\
\hline Tma & $\begin{array}{l}1670 \\
(1820)\end{array}$ & $\begin{array}{l} \pm 120 \\
( \pm 240)\end{array}$ & Ammonia Tanks Tuff \\
\hline Tmr & $\begin{array}{l}1740 \\
(1850)\end{array}$ & $\begin{array}{l} \pm 100 \\
( \pm 290)\end{array}$ & Rainier Mesa Tuff \\
\hline $\mathrm{Tp}$ & $\begin{array}{l}1630 \\
(1940)\end{array}$ & $\begin{array}{l} \pm 110 \\
( \pm 250)\end{array}$ & Paintbrush Group \\
\hline Tbg & $\begin{array}{l}1390 \\
(1980)\end{array}$ & $\begin{array}{l} \pm 180 \\
( \pm 160)\end{array}$ & Grouse Canyon Tuff \\
\hline Ttb & 1660 & \pm 100 & Tunnel beds \\
\hline Tub & 1600 & \pm 140 & Tub Springs Tuff \\
\hline & & $\begin{array}{l} \pm 350 \\
( \pm 550)\end{array}$ & cumulative standard deviation \\
\hline
\end{tabular}

The three different density functions yielded three different models of basin depths, representing a range of basement depths possible for the study area (table 2). The preferred model assumes the density contrast is $900 \mathrm{~kg} / \mathrm{m}^{3}$. This was chosen as a value for the central tendency of the density of the basin fill, representing a mix of volcanic rocks and Quaternary alluvium. The model referred to as the "lower" model represents the least dense end-member that is geologically reasonable, using a density contrast of $1000 \mathrm{~kg} / \mathrm{m}^{3}$, a model that represents a thick section of basin sediments composed almost entirely of relatively less-dense Tertiary tuffs (table 2). The model referred to as the "upper" model represents the most-dense end-member, the density-depth function previously generated from borehole gravity data in nearby Yucca Flat (Phelps and others, 1999). The borehole gravity data from Yucca Flat indicate density increases linearly with depth, with a standard deviation of $240 \mathrm{~kg} / \mathrm{m}^{3}$ for the residuals. This function was used to represent the upper limit of densities for the study area (table 2). All of the models included data in a $15 \%$ buffer area around the study area during the modeling process to minimize edge effects.

\begin{tabular}{|c|c|c|c|}
\hline \multicolumn{2}{|c|}{ Table 2. Density contrasts used in the lower, preferred, and upper model (left to right) } \\
\hline lower & $\begin{array}{c}\text { preferred } \\
\text { upper }\end{array}$ \\
\hline $\begin{array}{c}\text { Single density } \\
\text { contrast }\left(\mathrm{kg} / \mathrm{m}^{3}\right)\end{array}$ & $\begin{array}{c}\text { Single density } \\
\text { contrast }\left(\mathrm{kg} / \mathrm{m}^{3}\right)\end{array}$ & $\begin{array}{c}\text { Density contrast } \\
\left(\mathrm{kg} / \mathrm{m}^{3}\right)\end{array}$ & Depth (meters) \\
\hline \multirow{4}{*}{1000} & \multirow{3}{*}{900} & 850 & $0-200$ \\
\cline { 3 - 4 } & & 730 & $200-400$ \\
\cline { 2 - 4 } & & 610 & $600-600$ \\
\cline { 2 - 4 } & & 490 & $>800$ \\
\cline { 2 - 4 } & & 370 & $>800$ \\
\hline
\end{tabular}




\section{Results}

Some overall patterns can be seen from the results. First, the deepest part of the study area is in the northern part of the study area, in Emigrant Valley. The basin beneath Emigrant Valley is somewhat elongated north-south, deepening from the southern end of the valley to the north. This basin also seems to be shallower on the western half, suggesting that the basin could conceal a fault that has preferentially down-dropped the eastern half of the basin. However, the structure is not well-constrained by data and may be an artifact of the non-uniform spatial sampling within Emigrant Valley. Second, the next deepest basins, West Fork Scarp Canyon and Plutonium Valley, are less than half as deep as Emigrant Valley. These valleys are also elongated in a north-south direction. Third, a general trend can be seen in the pattern of depth in the study area south of Emigrant Valley. The Halfpint Range trends north-northwest, composed of sub-parallel ridges of pre-Tertiary basement outcrop. These outcrops become increasingly sparse to the southeast, along trend. As the outcrop area lessens, the inter-ridge basin depths become increasingly deep. This creates the overall sense that the pre-Tertiary outcrops making up the Halfpint Range plunge into the subsurface to the southeast. West Fork Scarp Canyon and Plutonium Valley are two subparallel valleys that demarcate the area when the pre-Tertiary rocks begin to plunge significantly below the surface.

The results of the modeling are shown in figures 4 and 5. As can be seen, lower density basin deposits result in shallower basins. Basins composed entirely of low-density tuffs would generate the measured gravity anomaly by filling only modest basins of less than $500 \mathrm{~m}$ depth in most of the study area. Only the basin in northern Emigrant Valley reaches a depth of nearly $1,000 \mathrm{~m}$. Alternatively, if the rocks and alluvium filling the basins in the study area are more dense and follow a pattern of increasing density similar to that seen in Yucca Flat, several deep basins occur that exceed 1,000m in depth, and Emigrant Valley is almost 2,500m at its deepest point. Between these two extremes the preferred model predicts a basement depth in Emigrant Valley of just over 1,000m, a depth in West Fork Scarp Canyon of almost 1,000m, and a depth of between $600 \mathrm{~m}$ and $800 \mathrm{~m}$ for much of Plutonium Valley. This is the model favored by the authors because it represents the most reasonable geologic interpretation of the possible basin-filling rocks and alluvium and most accurately predicts the basement depth at well ER-3-1. This model predicts a depth of $280 \mathrm{~m}$ to the pre-Tertiary basement at the location of drill-hole ER-3-1, where the drill-hole penetrated basement rocks at $293 \mathrm{~m}$ (figure 5). The lower model predicts a somewhat shallower depth of $245 \mathrm{~m}$, and the upper model predicts a depth of $318 \mathrm{~m}$. 

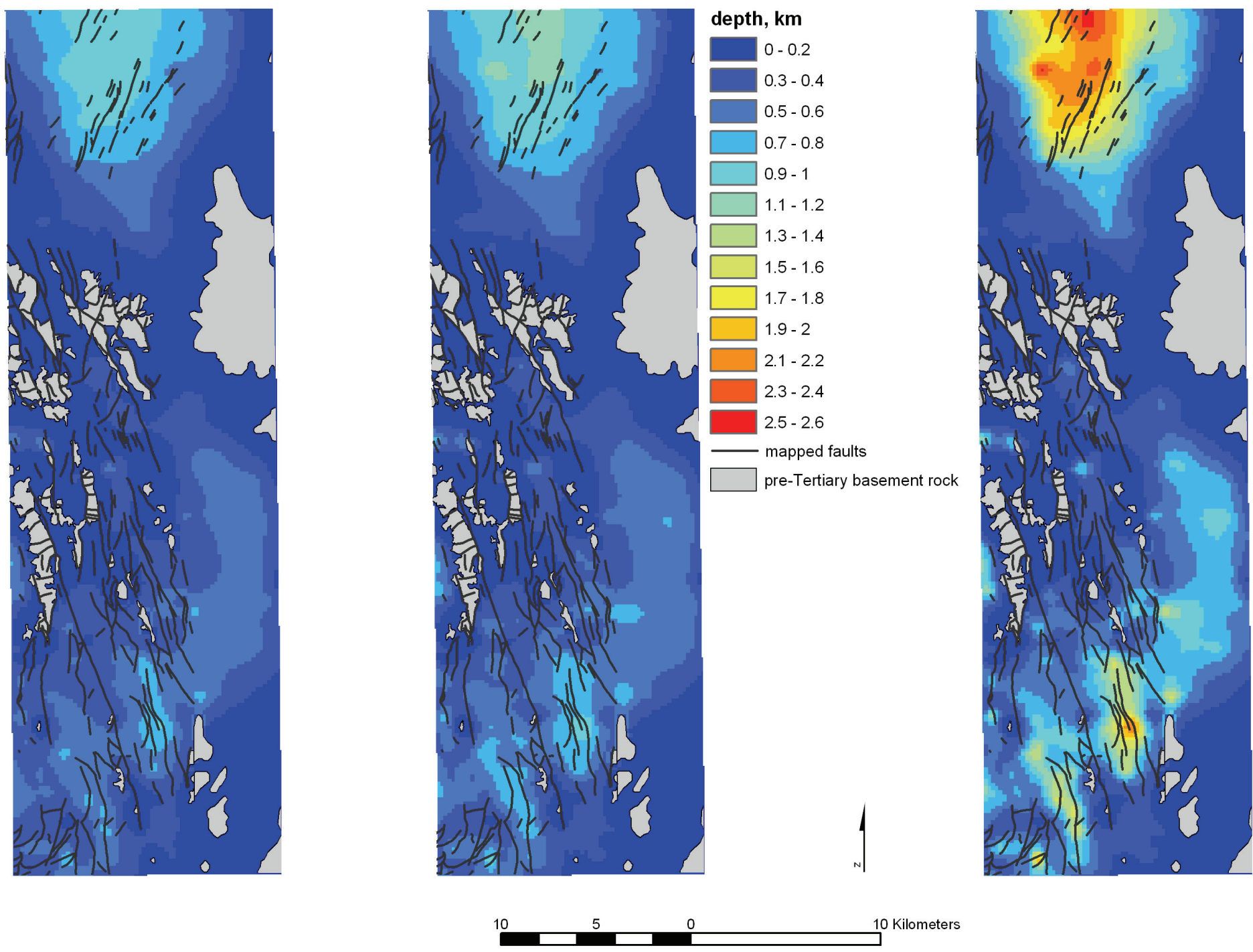

Figure 4. Three models of the depth to pre-Tertiary basement, left to right: less-dense Tertiary volcanic rocks, intermediate mixture of Tertiary and Quaternary volcanic rocks and sediments, and dense basin fill that increases in density with depth, based on previous work in Yucca Flat. Geology simplified from Wahl and others, 1997, Slate and others, 1999, and Raines and others, 2003. 

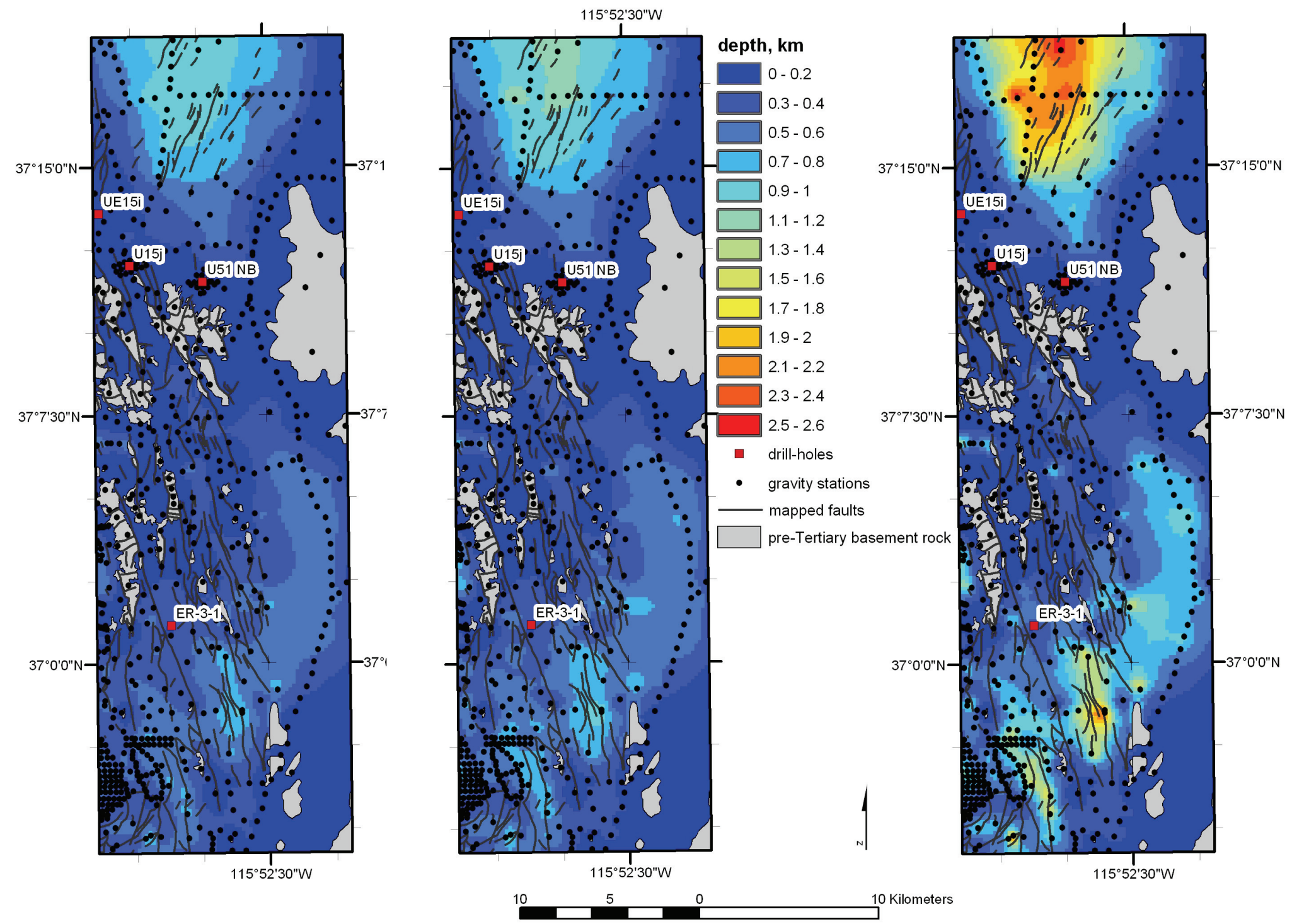

Figure 5. Models displayed in figure 4, with the addition of the location of gravity stations and drill-holes, for comparison to the modeling results. Geology simplified from Wahl and others, 1997, Slate and others, 1999, and Raines and others, 2003. 


\section{Uncertainty}

The factors contributing to uncertainty in the model are many, most stemming from insufficient data. As previously discussed, the isostatic residual gravity anomaly is generated by interpolating scattered data. Three aspects of uncertainty can be defined for the interpolation process: uncertainty due to the resolution (cell size) of the interpolated dataset, uncertainty due to sampling location, and bias from the interpolation algorithm used. Sparse scattered data necessarily produces uncertainty in the resolution of the interpolated surface, especially at distance from the data points. Figure 3 demonstrates that $50 \%$ of the study area is more than $600 \mathrm{~m}$ from the nearest data point, and therefore many of the cell values are interpolated when a cell size of $200 \mathrm{~m}$ is used. The scattered data are not evenly distributed, so some of the interpolated cells in the study area will be well-supported by nearby data, and some will be poorly-supported. The resolution of $200 \mathrm{~m}$ chosen for this study is a compromise between a detailed, smooth surface and a surface constrained by the data. The second aspect of uncertainty is caused by interpolating the dataset given the spatial arrangement of the gravity stations across the study area. The interpolation algorithm used was a bi-cubic spline (Briggs, 1974). The effect of the spatial distribution of the gravity stations on the bi-cubic spline interpolation algorithm can be investigated using cross-validation. "Leave-one-out" cross-validation (Mosteller and Tukey, 1977) was performed on the gravity data for the study area: given $\mathrm{n}$ gravity station measurements in the study area, $\mathrm{n}$ interpolated surfaces were generated by leaving out a different gravity station for each interpolation (each interpolation used n-1 gravity station measurements), then the interpolated value at the missing station was compared to the measured value at that gravity station and the difference recorded. An estimate of the distribution of the error due to interpolation is generated. The cross-validation root-mean-square error for the gravity dataset is $\pm 1.9 \mathrm{mGal}$. This is an estimate of the variation in the isostatic residual gravity surface due to interpolating the gravity measurements. To gain insight into the third aspect of uncertainty, the possible bias caused by the interpolation algorithm used, the scattered data were interpolated with a different interpolation algorithm, a regularized spline. The regularized spline (Mitasova and Mitas, 1993) represents one of many legitimate alternatives to the bi-cubic spline (Briggs, 1974) used to interpolate between the data points in the rest of this report. Like the bicubic spline, the regularized spline is an exact interpolator. The bi-cubic spline is sensitive to rapid changes in gradient indicated by the data. The resulting interpolated surface can become unstable and far exceed the local range of the data. The regularized spline has constraints in the equations defining the surface that reduce these instabilities (Mitasova and Mitas, 1993). The difference between the bi-cubic spline and the regularized spline is shown in figure 6 . The regularized spline tends to produce less extreme interpolated values, with many of the local minimums within the surface between 1 to $2 \mathrm{mGals}$ higher than those within the surface generated by the bi-cubic spline. Any bias caused by the interpolation method used to generate the isostatic residual gravity anomaly surface would be propagated through further gravity modeling. 


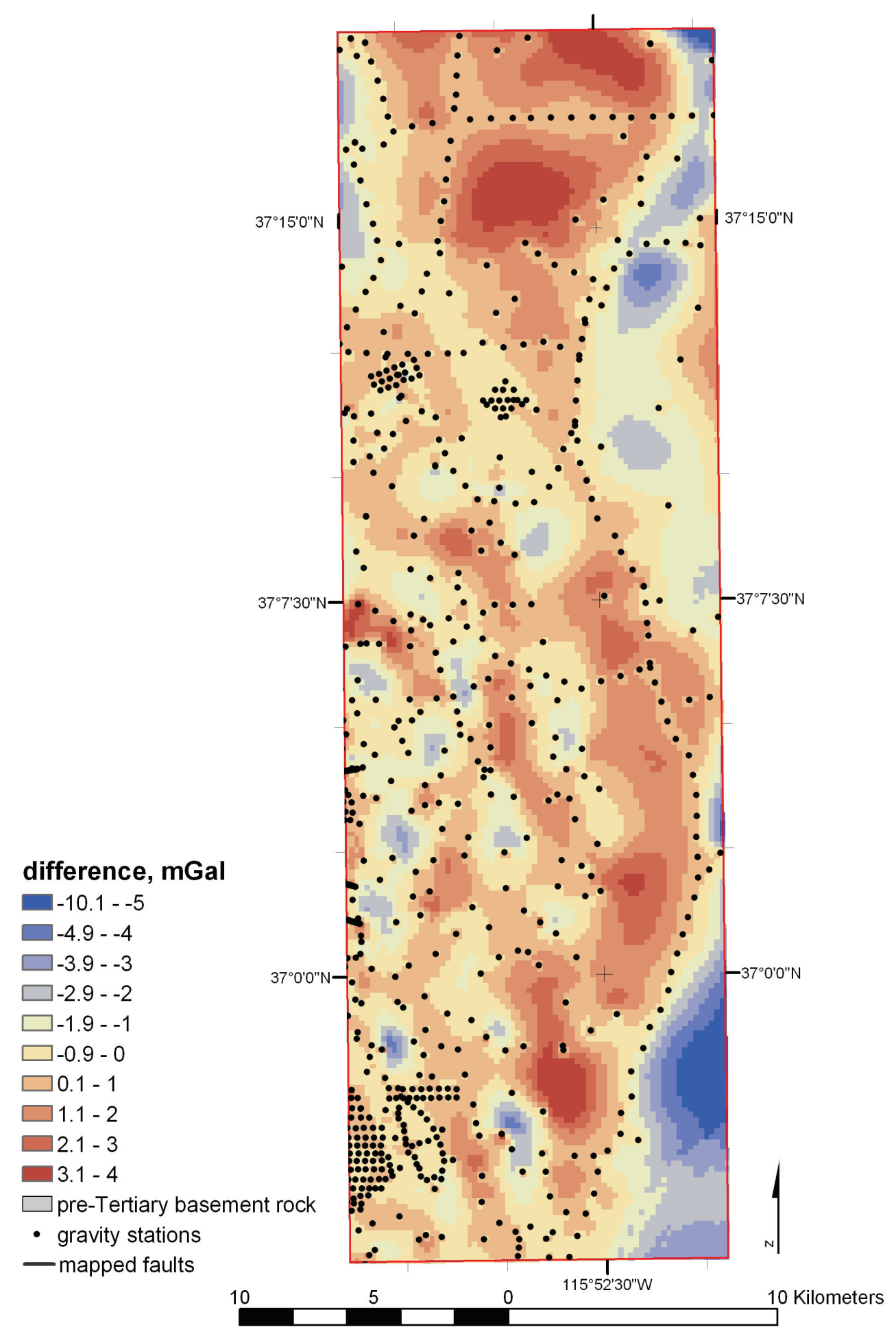

Figure 6. Map showing the difference between the bi-cubic spline interpolation algorithm and the regularized spline (figure shows the bi-cubic spline minus the regularized spline). Geology simplified from Wahl and others, 1997, Slate and others, 1999, and Raines and others, 2003. 
In addition to the uncertainty caused by the spatial arrangement of the gravity stations, lack of density data further complicates the problem. Three models were generated to attempt to capture the range of possible outcomes due to changes in density. Furthermore, each model result relies on a single density-depth function for the entire study area. In reality, the density-depth function is likely to be different for each local basin, and even locally within basins. While it will not be possible to capture all natural variation, it can be approximately captured and yield meaningful results (see, for example, Phelps and Graham, 2002, where the predicted model basin depth was within 5\% of the depth inferred from subsequently acquired drill-hole data). The variation within the models is positively correlated with depth. This is a function of the inverse relationship of rock density and predicted depth. As the difference in density between the basement rocks and the basin-filling rocks decreases, the depth of the basin (that is, the volume of rocks necessary to account for the measured gravity anomaly) increases asymptotically. Note that the difference in density can occur from a change in the estimated density of the basin-filling rocks or a change in the estimated density of $2670 \mathrm{~kg} / \mathrm{m}^{3}$ for the basement rocks. The range of depth at a given point defined by the models, therefore, will always be greater with greater predicted depth. The range of the model is shown graphically in figure 7. At shallow predicted depths the difference between the models is minimal. As depth increases the upper model diverges from the preferred model more dramatically than the lower model diverges from the preferred model. The asymmetrical behavior of the uncertainty is characteristic of this type of gravity inversion modeling. The approximate range of the models can be read directly from figure 7: find the depth of the preferred model on the $\mathrm{x}$-axis, then, reading the $\mathrm{y}$-axis, find the amount the depth would decrease for the lower model (blue circles) or the amount the depth would increase for the upper model (orange triangles). The range of the models is the difference between the lower and upper models. The spread among the data points themselves is due to the effect of local variations in the gravity anomaly.

The results for the small, shallow basins (less than 500m deep) will likely not change dramatically with the addition of new data. This is because the gravity anomaly over small areas can be approximately characterized with few data points and large structural anomalies, if present, would be detected. Additionally, the range of depths for shallow basins is small, so that the depths will not change significantly even given a wide possible range of densities for the basin deposits. The depth estimates for the larger basins, however, including Emigrant Valley could change dramatically with the addition of new data, if the new data were to cross a large structure currently not visible due to sparse sampling. 


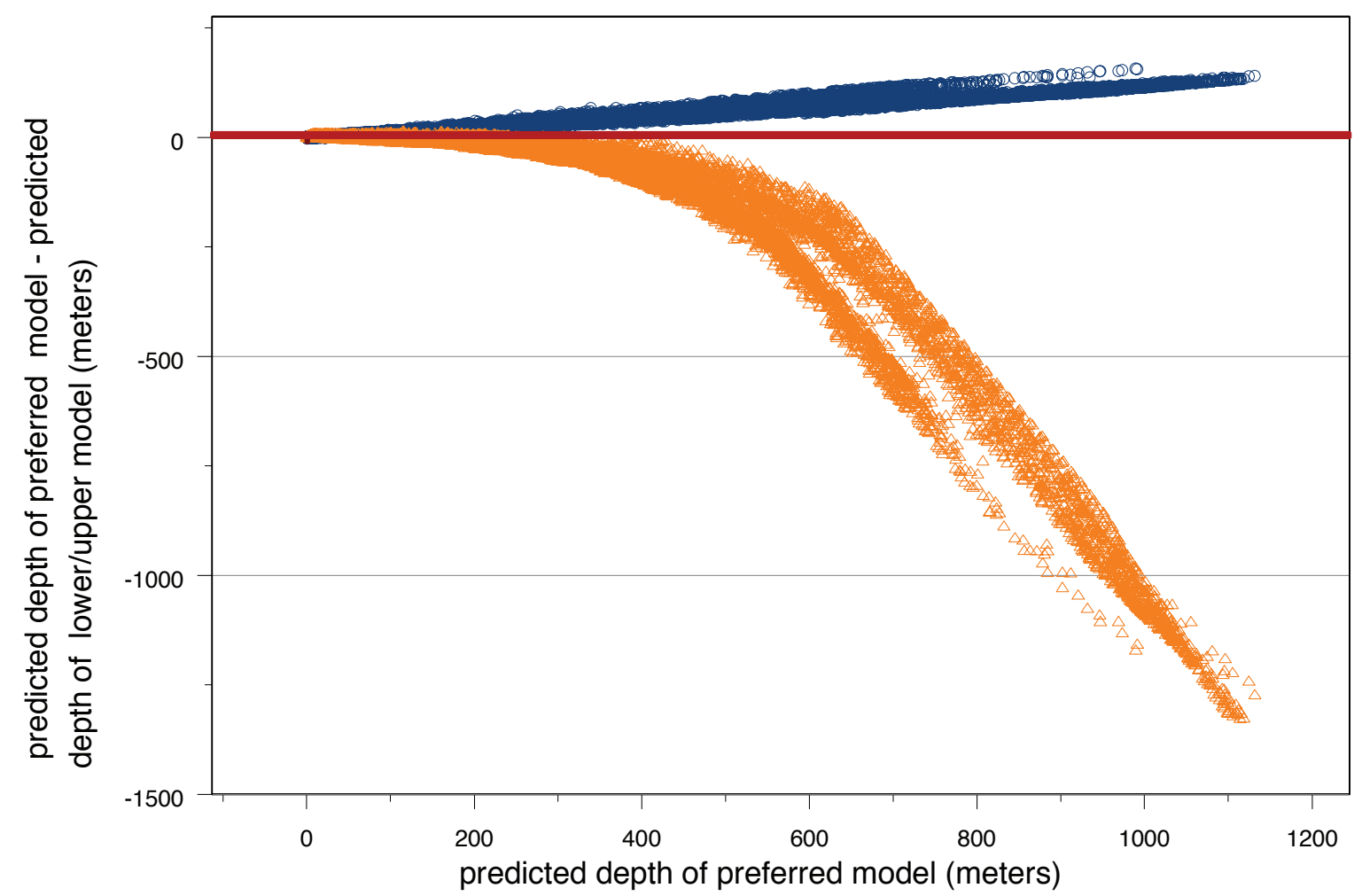

Figure 7. Graph of the difference between the predicted depth to pre-Tertiary basement of the preferred model and the lower (blue) and upper (orange) models. The figure shows how the difference in the predicted depth of the models changes non-linearly with depth; the deeper the predicted depth of the preferred model, the greater the difference between the predictions of all of the models. Red line indicates no difference with the preferred model (preferred model - preferred model $=0$ ).

Many of the locally deep sub-basins that occur in throughout the study area are defined by one data point. Error in such a data point would affect the local region of the model. Alternatively, the point may represent a structure that sparse sampling cannot define. More sampling is required to resolve this issue. Local high or low values of depth not supported by bedrock outcrop or a data point should be considered a consequence of interpolating sparsely sampled data and interpreted carefully.

\section{Conclusion}

The eastern extension study area was modeled using the isostatic residual gravity anomaly to estimate the depth to pre-Tertiary basement rocks beneath the Tertiary volcanic and sedimentary rocks and Quaternary alluvium. Three models were created: a preferred model based on the preferred estimate of the density of the basin rocks, and two models based on higher and lower density values, created to bracket the preferred model and estimate the uncertainty of the result. The preferred model predicts a maximum depth of approximately 1,100m for Emigrant Valley, the deepest basin in the model. South of Emigrant Valley the basement rocks outcrop in the Halfpint Range, and only very shallow sedimentary cover exists. As the Halfpint Range trends south, basin depths reach a maximum of 1,000m in West Fork Scarp Canyon and $800 \mathrm{~m}$ in Plutonium valley. 
The models show the general structural trends of the basins within the study area. Although most of the basins are too shallow to conceal significant structures, a possible north-trending structure exists beneath Emigrant Valley, permitted but not confirmed due to the sparse data available in the area. The model results also indicate that the valleys West Fork Scarp Canyon and Plutonium Valley are less than half as deep as Emigrant Valley and are elongated in a north-south direction. West Fork Scarp Canyon and Plutonium Valley form two sub-parallel valleys, defining the area where the pre-Tertiary rocks of the Halfpint Range plunge southward below the surface.

The models indicate that the range of depths of possible throughout the study area are within approximately $200 \mathrm{~m}$ of the preferred model, except in the deeper parts of Emigrant Valley, where the maximum depth ranges from $1,000 \mathrm{~m}$ for the least deep model and 2,450m for the deepest model. Predicted maximum basement depths in West Fork Scarp Canyon range from $800 \mathrm{~m}$ to $2100 \mathrm{~m}$, and in Plutonium Valley they range from $650 \mathrm{~m}$ to $1500 \mathrm{~m}$. The preferred model predicts maximum depths of approximately $1100 \mathrm{~m}$ for Emigrant Valley, 1000m for West Fork Scarp Canyon, and 800m for Plutonium Valley.

\section{References Cited}

Barnes, H., Christiansen, R. L., and Byers, F.M. Jr., 1965, Geologic map of the Jangle Ridge Quadrangle, Nye and Lincoln Counties, Nevada: U.S. Geological Survey, scale 1:24,000.

Briggs, I., 1974, Machine contouring using minimum curvature: Geophysics, v. 39, no. 1, 39-48.

Burkhard, N.R., 1989, Physical properties in LLNL Yucca Flat Areas: the rock pile concept: $5^{\text {th }}$ Symposium of the Containment of Underground Nuclear Detonations, Mission Research in Santa Barbara, California, September 19-21, 1989.

Byers, F.M. Jr., and Barnes, H., 1967, Geologic map of the Paiute Ridge Quadrangle, Nye and Lincoln Counties, Nevada: U.S. Geological Survey, scale 1:24,000.

Cole, J. C., Harris, A. G., and Wahl, R. R., 1997, Sub-crop geologic map of pre-Tertiary rocks in the Yucca Flat and northern Frenchman Flat areas, Nevada Test Site, southern Nevada: U.S. Geological Survey Open-File Report 97-678, 24 p.

Gonzales, J. L., S. L. Drellack, and M. J. Townsend, 1998, Written communication prepared for DOE/NV, Subject: "Descriptive Narrative for the Hydrogeologic Model at the Yucca Flat Corrective Action Unit.” An interim report. Bechtel Nevada, Las Vegas, NV.

Gonzales, J. L., and S. L. Drellack. 1999, Written communication prepared for DOE/NV, Subject: "Addendum to the Descriptive Narrative for the Hydrogeologic Model of the Yucca Flat Corrective Action Unit: Northern Extension.” Bechtel Nevada, Las Vegas, NV.

Hinrichs, N. E., and McKay, E. J., 1965, Geologic map of the Plutonium Valley Quadrangle, Nye and Lincoln Counties, Nevada: U.S. Geological Survey, scale 1:24,000.

International Union of Geodesy and Geophysics, 1971, Geodetic Reference System 1967: 
International Association of Geodesy Special Publication 3, 116 p.

Jachens, R. C., and Griscom, A., 1985, An isostatic residual gravity map of California -- A residual map for interpretation of anomalies from intracrustal sources; in Hinze, W.J. ed., The utility of regional gravity and magnetic anomaly maps: Tulsa, Okla., Society of Exploration Geophysics, p. 347-360.

Jachens, R.C., and Moring, B.C., 1990, Maps of the thickness of Cenozoic deposits and the isostatic residual gravity over basement for Nevada: U.S. Geological Survey Open-File Report 90-404, 15 p., 2 plates, scale 1:1,000,000.

Mitasova, H., and Mitas, L., 1993, Interpolation by regularized spline with tension: I. theory and implementation; Mathematical Geology, v. 25, no. 6, p. $641-655$.

Morelli, C. (ed.), 1974, The International Gravity Standardization Net, 1971: International Association of Geodesy Special Publication 4, 194 p.

Mosteller, F., and Tukey, J.W., 1977, Data Analysis and Regression: A Second Course in Statistics; Addison-Wesley, Reading, Massachusetts, 588 p.

Phelps, G.A., Langenheim, V.E., and Jachens, R.C., 1999, Thickness of Cenozoic deposits of Yucca Flat inferred from gravity data, Nevada Test Site, Nevada: U.S. Geological Survey Open-File Report 99-310, 32 p.

Phelps, G.A., and Graham, S.E., 2002, Preliminary gravity inversion model of Frenchman Flat basin, Nevada Test Site, Nevada: U.S. Geological Survey Open-File Report 02-363, 22 p.

Plouff, D., 1977, Preliminary documentation for a FORTRAN program to compute gravity terrain corrections based on topography digitized on a geographic grid: U.S. Geological Survey OpenFile Report 77-535, 45 p.

Ponce, D.A., 1997, Gravity data of Nevada: U.S. Geological Survey Digital Data Series DDS-42, CD-ROM.

Raines, G.L., Connors, K.A., Moyer, L.A., and Miller, R.J., 2003, Spatial digital database for the geologic map of Nevada, USGS Open file report 03-066.

Saltus, R.W., and Jachens, R.C., 1995, Gravity and basin-depth maps of the Basin and Range Province, western United States: U.S. Geological Survey Geophysical Investigations Map GP1012 , scale $1: 2,500,000$

Slate, J.C., Berry, M.E.,Rowley, P.D., Fridrich, C.J., Morgan, K.S., Workman, J.B., Young, O.D., Dixon, G.L., Williams, B.S., McKee, E.H., Ponce, D.A., Hildenbrand, T.G., Swadley, W.C., Lundstrom, S.C., Ekren, E.B., Warren, R.G., Cole, J.C., Fleck, R.J., Lanphere, M.A., Sawyer, D.A., Minor, S.A., Grunwald, D.J., Laczniak, R.J., Menges, C.M., Yount, J.C., and Jayko, A.S., 1999, Digital Geologic Map of the Nevada Test Site and Vicinity, Nye, Lincoln, and Clark 
Counties, Nevada, and Inyo County, California: U.S. Geological Survey Open-File Report 99554, scale 1:100,000.

Stewart, J. H., and Carlson, J. E., 1978, Geologic map of Nevada: Reston, Va.: U.S. Geological Survey, scale 1:500,000.

Wahl, R.R., Sawyer, D.A., Carr, M.D., Minor, S.M., Cole, J.C., Swadley, W.C., Laczniak, R.J., Warren, R.G., Green, K.S., and Engle, C.M., 1997, Digital geologic map database of the Nevada Test Site area, Nevada: U.S. Geological Survey Open-File Report 97-140, scale $1: 100,000,47 \mathrm{p}$.

Winograd, I.J., and Thordarson, W., 1975, Hydrogeologic and hydrochemical framework, south central Great Basin, Nevada-California, with special reference to the Nevada Test Site: U.S. Geological Survey Professional Paper 712-C, 126 p. 